\title{
Batı Akdeniz Yöresi doğal sedir meşcereleri için hacim denklemleri
}

\author{
Ramazan Özçelik ${ }^{\text {a,** }}$, Meryem Çevlik ${ }^{\mathrm{b}}$
}

\begin{abstract}
Özet: Toros sediri (Cedrus libani A. Rich.) ülkemizin ekolojik ve ekonomik açıdan en önemli ağaç türlerinden birisidir. Bu nedenle, sedir ormanlarının bugün ve geleceğe dönük yönetim ve planlama stratejilerinin geliştirilmesinde, türün büyüme ve hasılatına ilişkin bilgilere ihtiyaç duyulmaktadır. Ormanların büyüme ve hasılatına ilişkin tahminlerde kullanılan en önemli yapı taşlarından birisi, ağaç hacim tahminleridir. Bu amaçla, çalışmada Batı Akdeniz Yöresi doğal Toros sediri meşcerelerinin hacim tahminleri için hacim denklemleri geliştirilmiştir. En uygun hacim denkleminin seçimi; model geliştirme ve test verileri için, altı farklı uygunluk ölçütü (uyum indeksi, ortalama hata, ortalama mutlak hata, maksimum mutlak hata, hata kareler ortalamasının karekökü ve Akaike bilgi kriteri) kullanılarak belirlenen model nisbi sıralamalarına göre gerçekleştirilmiştir. Model nisbi sıralarına göre, en başarılı hacim modelleri, Takata (1958) ve Schumacher ve Hall (1933)'dir. Ancak, yörede doğal sedir meşcerelerinde yapılacak ağaç hacim tahminleri için, yaygın olarak kullanılan ve nispeten daha kolay bir model olması nedeniyle, Schumacher-Hall (1933) hacim denklemi önerilmiștir.
\end{abstract}

Anahtar kelimeler: Sedir, Hacim denklemi, Göğüs çapı, Boy, Nisbi sıra

\section{Volume equations for natural Taurus cedar stands in West Mediterranean Region}

\begin{abstract}
Taurus cedar (Cedrus libani A. Rich.) is one of the most important tree species in Turkey. Therefore, the information is necessary about growth and yield of the species for developing future management and planning strategies. The one of the essential building blocks in forest growth and yield prediction models is the equations for estimating individual tree volume. In this study, tree volume equations were developed for Taurus cedar stands in West Mediterranean Region. The tested models were compared using six performance criteria (Fit index, average bias, average absolute residuals, absolute maximum bias, and Akaike Information criteria) for model development and validation dataset. According to relative ranks of models, the best volume equations are Takata (1958) and Schumacher-Hall (1933) for Taurus cedar. As a result, tree volume can be estimated with high precision using Schumacher-Hall (1933)'s equation for natural cedar stands in this region.

Keywords: Taurus cedar, Volume equation, Diameter, Height, Relative rank
\end{abstract}

\section{Giriş}

Ülkemizde orman kaynaklarının planlanmas çalışmaları, 2008 yılında yürürlüğe giren yeni amenajman yönetmeliğine göre, ekos istem tabanlı fonksiyonel planlama ilkelerine uygun bir şekilde gerçekleştirilmektedir. Ekosistem tabanlı fonksiyonel planların düzenlenebilmesi, bu planlara bağlı olarak ormanların iş letilmesi ve ormanların sürdürülebilir yönetimi için ağaç türlerine ilişkin dinamik büyüme ve hasılat modellerine ihtiyaç duyulmaktadır. Büyüme ve hasılat modellerinin en önemli altlıklarından birisi ağaç ve meşcere hacim tahmin leridir.

Hacim tahminleri, ağaç ve meşcerelere iliş kin hacmin ve bu hacim miktarının farklı ticari sınıflara dağılımının doğru hesaplanmasinda (Dieguez-Aranda vd. 2006; CrecenteCampo vd., 2009), orman amenajman planlarının düzenlenmesinde (de-Miguel vd., 2012; Rodríguez vd. 2014), orman ürünleri sanayisinin geleceğine ilişkin projeksiyonların yapılmasinda (Fang vd., 2000; Jiang vd., 2005; de-Miguel vd., 2012) ve uygun biyokütle dönüşüm faktörleri yardımı ile biyokütle ve karbon birikim miktarının hesaplanmasinda (Castedo-Dorado vd., 2012; Gomez-
Garcia vd., 2015) kullanılan önemli bir meşcere parametresidir. Bu nedenle; ülkemizde, tek ağaç hacminin en doğru şekilde belirlenmesine olanak veren, büyüme ve has 1lat modellerine entegre edilebilen, esnek ve güvenilir hacim tahmin metotlarına ihtiyaç duyulmaktadır(de-Miguel vd., 2012).

Hacim denklemleri veya ağaç hacim tabloları geçmiş̧ten günümüze dikili bir ağacın gövde hacmini ya da kalın odun hacmini tahmin etmek amacıyla en çok kullanılan yöntemlerden biridir. Ağaç hacmi; gögüs yüksekliği çap1 $(d)$, ağaç boyu $(h)$ ve göğüs boyu ş ekil katsayıs ının (şekil faktörü) $(f)$ bir fonksiyonu olarak tahmin edilmektedir. Ancak, pek çok araştırmacı gövde hacmi ve ağırlık denklemlerinin geliştirilmesinde șekil katsayısını bir değişken olarak kullanmamayı tercih etmektedirler (Clutter vd., 1983; Husch vd., 2003).

Ağaç hacim tablolarının düzenlenmes inde, genel olarak tek girişli, çift girişli ya da çok girişli ağaç hacim denklemleri kullanılmaktadır. Ağaç hacim denklemlerinde bir, iki veya ikiden fazla bağımsız değişken kullanmasına bağlı olarak sırasıyla, tek girişli, çift girişli ve çok girişli ağaç hacim denklemi isimlerini almaktadır. Geçerli

\footnotetext{
a Süleyman Demirel Üniversitesi, Orman Fakültesi, Isparta.

b Süleyman Demirel Üniversitesi, Fen Bilimleri Enstitüsü, Orman Mühendisliği Ana Bilim Dalı, Isparta

@ * Corresponding author (İletişim yazarı): ramazanozcelik@ sdu.edu.tr

$\checkmark$ Received(Geliş tarihi): 01.12.2016, Accepted(Kabul tarihi): 14.02.2017
}

Citation (Atıf): Özçelik, R., Çevlik, M., 2017. Batı Akdeniz Yöresi doğal sedir meşcereleri için hacim denklemleri. T urkish Journal of Forestry, 18(1): $37-48$ DOI: $10.18182 /$ tjf. 270694 
oldukları alanın büyüklüğüne göre de "Yöresel (Lokal) Ağaç Hacim Denklemleri”, "Bölgesel Ağaç Hacim Denklemleri” ve "Genel Ağaç Hacim Denklemleri” olmak üzere üç gruba ayrılmaktadır (Burkhart ve Tome, 2012).

Ağaç hacim denklemlerinin geliştirilmesi amaciyla yapılan çalışmalarda, oldukça fazla sayıda ve farklı tipte modelin kullanıldı̆̆ 1 görülmektedir (Ritchie ve Hann, 1984; Burk vd., 1989; Hjelm ve Johansson, 2012; Rachid vd., 2014). Ülkemizde, çeşitli araştırmacılar tarafından bazı asli ağaç türleri için yöresel ağaç hacim denklemleri geliştirilmiştir (Saraçoğlu, 1988; Bozkuş ve Carus, 1997; Yavuz, 1999; Özkurt, 2002; Misır ve Misır, 2004; Sakıc1 ve Yavuz, 2005; Özçelik, 2010)

Ülkemizde, ekosistem tabanlı fonksiyonel planlama çalışmalarının başarıyla gerçekleştirilebilmesi, farklı yetişme ortamlanı ve bu yetişme ortamlarındaki tek ağaç ve meşcereler için düzenlenmiş ağaç hacim denklemlerinin bulunmasını zorunlu hale getirmiștir. Ancak, orman amenajman planları incelendiğinde, aynı hacim tablosunun yetişme ortamı farklılıkları dikkate alınmadan geniş coğrafi bölgeler içerisinde kullanıldığı da çoğu zaman göze çarpmaktadır. Bunun sonucu olarak, gövde hacim tahminlerinde oldukça büyük hataların ortaya çıkabildiği değişik çalışmalarda ortaya konulmuştur (Özçelik, 2010; Brooks vd., 2008; Özçelik ve Alkan, 2016). Pillsbury vd. (1995); aynı hacim tablosunun farklı yetişme ortamı özelliklerine sahip yörelerde kullanılması ile ortaya çıkacak hacim hatas ının \%40'a kadar yüks elebileceğini belirtmiştir. $\mathrm{Bu}$ nedenle; eldeki olanaklar izin verdiği müddetçe farklı yetişme ortamı özelliklere sahip alanlar için farklı hacim tablolarının düzenlenmesi gerektiği vurgulanmaktadır (Brooks ve Wiant, 2008). Özellikle, ülkemiz gibi tür çeşitliliğinin ve yetişme ortamı farklılıklarının yüksek olduğu yerlerde, her yöre ve tür için ayrı yöresel hacim denklemlerinin geliştirilmesi, doğru ve güvenilir hacim tahminleri için gerekli ve zorunludur.

Toros sediri, ülkemiz için ekolojik ve ekonomik açıdan en önemli ağaç türlerinden biridir. Türün, doğal yayılış gösterdiği Suriye ve Lübnan'da plansız üretim, aşırı otlatma ve yangınlar gibi sebeplerle varlığı neredeyse tükenmiş, yayılış alanı ülkemiz ile sınırlı bir hal almıştır (Boydak, 2003). Bu nedenle, doğal sedir ormanları ülkemiz için, korunmas1 gereken en önemli kültürel miras, doğal hazine ve anitlar niteliğindedir. Sedir ormanları; toprak ve su kaynaklarının korunması, ilkim değişiminin olumsuz etkisinin azaltılması ve buna adaptasyon sağlanması ve biyolojik çeşitliliğin korunması gibi önemli çevresel konularda anahtar bir role sahiptir.

Diğer yandan, sedir değerli ve çok yönlü kullanıma sahip odunu nedeniyle de halen önemli bir ekonomik değere sahiptir ve piyasada yüksek miktarda talebe konu olmaktadır. Bu çerçevede, sedir ormanlarının bir taraftan korunmas1, diğer taraftan da sürdürülebilir işletilmesi amaciyla, geleceğe dönük planlama ve stratejilerin oluşturulması için bu ormanların mevcut durumuna, büyüme ve gelişme özelliklerine ilişkin güvenilir ve nitelikli bilgilere ihtiyaç bulunmaktadır. A ğaç hacim tahminleri de; bir türün en önemli büyüme ve gelişme parametrelerinden biridir. 2012 yılı orman envanteri sonuçlarına göre, sedir, yaklașı 463.500 ha alanda yayılış göstermekte ve bu alanlar üzerindeki dikili ağaç serveti de, yaklaşık olarak 27 milyon $\mathrm{m}^{3}$ civarındadır. Bu orman alanlarının çok büyük bir kısmı Akdeniz Bölgesinde, özellikle Antalya ve Mersin Orman
Bölge Müdürlükleri (\%65) içerisindedir. Antalya Orman Bölge Müdürlüğü'ne bağlı Orman İşletme Şefliklerinin amenajman planları incelendiğinde; toplams edir alanlarının yaklaşık \%28'inin Antalya Orman Bölge Müdürlüğü sınırları içerisinde kaldığı ve Batı Akdeniz Bölgesi (Elmalı, Kaş ve Kumluca Orman İşletme Müdürlükleri) içerisinde yer alan doğal sedir meşcerelerinin ise bu alanların yaklaş $1 \mathrm{k}$ \%50'sini oluşturduğu görülmüştür.

$\mathrm{Bu}$ çalışmada, Batı Akdeniz Bölgesi doğal sedir meşcereleri için ağaç hacim denklemleri geliştirilmiştir. $\mathrm{Bu}$ amaçla değişik formlarda 30 adet ağaç hacim denklemi seçilmiş, model geliştirme ve bağımsız veri setleri kullanılarak test edilmiş ve yöre için en uygun ağaç hacim denklem veya denklemlerinin belirlenmes ine çalışılmıştır.

\section{Materyal ve yöntem}

\subsection{Materyal}

Örnek ağaç verileri, Antalya Orman Bölge Müdürlüğü Elmalı, Kaș ve Kumluca Orman İșletme Müdürlüklerinin sırasıyla; Çığlıkara, Sütleğen, Gömbe ve Yukarıalakır Orman İşletme Şefliklerindeki doğal sedir meşcerelerinden toplanmıştır. $\mathrm{Bu}$ amaçla toplam 427 adet örnek ağaç ölçülmüş, bu verilerin rasgele yöntemle, yaklaşı $1 \mathrm{\%} 75$ 'i (329 ağaç) model geliştirmek, geri kalan yaklaşık \%25'lük (98) kısmı ise geliştirilen modellerin test edilmesi amacıyla ayrılmıştır. Örnek ağaçların seçiminde, ağaçların meşcere kuruluşlarını ve dolayısıyla farklı çap ve boy sınıflarını en iyi şekilde temsil etmesini sağlamak amaciyla, tüm çap ve boy sinıflarına eşit dağılımının sağlanmasına dikkat edilmiştir. Örnek ağaçlar hem galip hem de müşterek galip ağaçlar arasından seçilmiştir. Örnek ağaçların seçiminde gövdelerin çatallı ve eğri, tepelerin kırı olmamasına ve yetişme ortamı koşullarını en iyi biçimde yansıtmasına dikkat edilmiştir. Örnek ağaçların çap1 $(d)$, elektronik çap ölçer yardımı ile $0.1 \mathrm{~cm}$, boyu $(h)$ ise laser boy ölçer yardımı ile $0.05 \mathrm{~m}$ hassasiyetle ölçülmüştür. A ğaç hacimlerinin belirlenmesi amaciyla Bailey (1995) tarafindan önerilen üst üste eklemeli seksiyon metodu (the overlapping bolt method) kullanılmıştır. Ölçümü yapılan tüm ağaçların çap-boy dağılım grafiği Şekil 1'de verilmiştir.

Model geliştirmek ve geliştirilen modellerin test edilmesi amacıyla kullanılan örnek ağaçların çap ve boy sınıflarına dağılımları Çizelge 1 ve 2'de verilmiştir. Çizelge 3'te ise ölçümü yapılan örnek ağaçların çap, boy ve hacim değerlerine ilişkin nitelendirici is tatistikler bulunmaktadır.

\subsection{Yöntem}

Ormancılık çalışmalarında; 50 yılı aşkın zamandır pek çok ağaç hacim denklemi geliştirilmiştir (Scott, 1981; Clutter vd., 1983; Kelly ve Beltz, 1987; Saraçoğlu, 1988; van Laar ve Akça, 1997; Fowler, 1997; Yavuz, 1999; Teshome 2005; Akindele ve LeMay, 2006; Perez, 2008). Çalışmada çeşitli kaynaklardan temin edilen farklı formlardaki hacim fonksiyonları kullanılmıştır (Yavuz, 1999; Bi ve Hamilton, 1998; Misır ve Misır, 2004; Alegria ve Tome, 2011; Hjelm ve Johansson, 2012). Bu fonksiyonlara ilişkin detaylı açıklamalar aşağıda verilmiştir: 


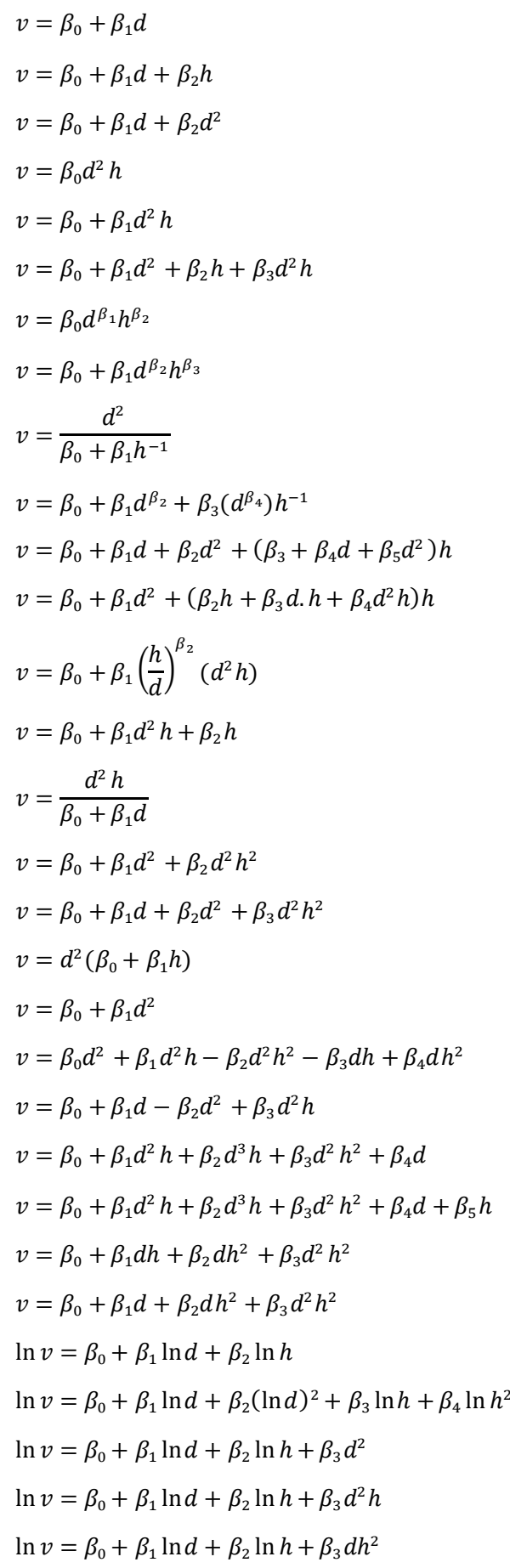

(Pehlivan, 2004)

(Multiple Linear)

(Hohenadl-Krenn, 1899)

(Spurr, 1982)

(Spurr, 1952)

(Graves, 1978)

(Schumacher-Hall, 1933)

(Schumacher-Hall, 1933)

(Honer, 1967)

(Scott, 1979)

(Spurr, 1952)

(Naslund, 1947)

(Teshome, 2005)

(Casnati, 2014)

(Takata, 1958)

(Alegria ve Tome, 2011)

(Alegria ve Tome, 2011)

(Ogaya, 1968)

(Kopezky, 1899)

(Eriksson, 1973)

(Opdahl, 1992)

(Bi ve Hamilton, 1998)

(Bi ve Hamilton, 1998)

(Alegria ve Tome, 2011)

(Alegria ve Tome, 2011) 
Çizelge 1. Model geliştirme verilerinin çap ve boy basamaklarına dağılımı

\begin{tabular}{|c|c|c|c|c|c|c|c|c|c|c|c|c|c|}
\hline \multirow{2}{*}{$\begin{array}{l}\text { Çaplar } \\
\text { (cm) }\end{array}$} & \multicolumn{12}{|c|}{ Boylar (m) } & \multirow{2}{*}{$\Sigma$} \\
\hline & 7 & 9 & 11 & 13 & 15 & 17 & 19 & 21 & 23 & 25 & 27 & 29 & \\
\hline 10 & 1 & & & & & & & & & & & & 1 \\
\hline 14 & & 10 & 6 & & & & & & & & & & 16 \\
\hline 18 & 1 & 5 & 17 & 12 & 2 & & & & & & & & 37 \\
\hline 22 & & 1 & 11 & 11 & 8 & 6 & 1 & & & & & & 38 \\
\hline 26 & & & 5 & 15 & 12 & 11 & 3 & 2 & & & & & 48 \\
\hline 30 & & & & 4 & 10 & 13 & 15 & 10 & 1 & & & & 53 \\
\hline 34 & & & & & 3 & 17 & 6 & 11 & 8 & 2 & 1 & & 48 \\
\hline 38 & & & & & 2 & 5 & 8 & 11 & 8 & 4 & 3 & 1 & 42 \\
\hline 42 & & & & & & 3 & 5 & 7 & 7 & 5 & 1 & & 28 \\
\hline 46 & & & & & & 1 & 3 & & 5 & 3 & 1 & & 13 \\
\hline 50 & & & & & & & 1 & & 2 & & 1 & & 4 \\
\hline 54 & & & & & & & & & & & 1 & & 1 \\
\hline$\Sigma$ & 2 & 16 & 39 & 42 & 37 & 56 & 42 & 41 & 31 & 14 & 8 & & 329 \\
\hline
\end{tabular}

Çizelge 2. Model test verilerinin çap ve boy basamaklarına dağılımı

\begin{tabular}{lrlllllllllr}
\hline $\begin{array}{c}\text { Caplar } \\
\text { (cm) }\end{array}$ & 9 & 11 & 13 & 15 & 17 & 19 & 21 & 23 & 25 & 27 & $\Sigma$ \\
\hline 10 & 2 & & & & & & & & & & 2 \\
14 & 5 & 2 & 1 & & & & & & & \\
18 & 4 & 2 & 5 & 1 & & & & & & \\
22 & & 1 & 2 & 1 & & & 1 & & & & 12 \\
26 & & 1 & 8 & 1 & 2 & & 1 & & & & 5 \\
30 & & & & 7 & 4 & 3 & & & & & 13 \\
34 & & & & & 2 & 1 & 4 & 2 & & & 14 \\
38 & & & & & 2 & 3 & 1 & 2 & 2 & & 10 \\
42 & & & & & 3 & 3 & 2 & 5 & & 3 & 16 \\
46 & & & & & & 1 & 1 & 3 & 3 & 1 & 9 \\
\hline$\Sigma$ & 11 & 6 & 16 & 10 & 13 & 11 & 10 & 12 & 5 & 4 & 98 \\
\hline
\end{tabular}

Çizelge 3. Çalışmada kullanılan örnek ağaçlara ilișkin nitelendirici istatistikler

\begin{tabular}{|c|c|c|c|c|c|c|c|c|}
\hline \multirow{2}{*}{ Değişkenler } & \multicolumn{4}{|c|}{ Model geliştirme verileri $(n=329)$} & \multicolumn{4}{|c|}{ Model test verileri $(\mathrm{n}=98)$} \\
\hline & Ortalama & Min. & Max. & S.D. & Ortalama & Min. & Max. & S.D. \\
\hline$\overline{\mathrm{DBH}}(\mathrm{cm})$ & 29.82 & 11.30 & 53.00 & 8.92 & 30.30 & 10.80 & 47.80 & 10.16 \\
\hline $\mathrm{TH}(\mathrm{m})$ & 17.05 & 7.40 & 30.20 & 4.72 & 16.92 & 8.10 & 27.60 & 5.23 \\
\hline $\mathrm{V}\left(\mathrm{m}^{3}\right)$ & 0.6356 & 0.0358 & 2.2904 & 0.47 & 0.6686 & 0.0360 & 1.8367 & 0.5068 \\
\hline
\end{tabular}

DBH: göğüs çapı; $T H$ : Toplam ağaç boyu; $V$ : hacim.

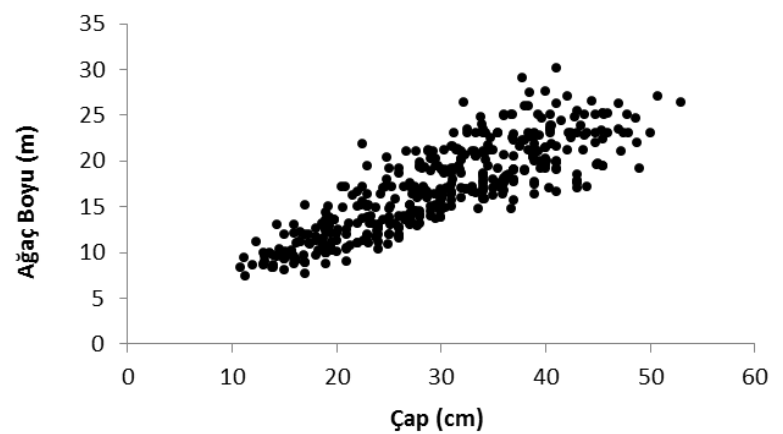

Şekil 1. Ölçümü yapılan örnek ağaçlara ilişkin çap-boy dağılım grafiğ $i$

Çalışmada, 1 ve 19 nolu (tek girişli ağaç hacim denklemi) ağaç hacim denklemleri dışındaki denklemler, çift giriş li ağaç hacim denklemidir.

Yukarıda verilen doğrusal ve doğrusal olmayan regres yon denklemlerinin çözümü için doğrusalve doğrusal olmayan en küçük kareler yöntemleri kullanılmıştır. Çalışmada bazı logaritmik denklemler de test edilmiştir. Ancak bu modeller ağaç gövde hacminin logaritmasını göğüs çap1 ve ağaç boyunun logaritmasina göre vermektedir. Gerçek gövde hacim değerlerinin hesaplanabilmesi için elde edilen logaritmik değerlerin antilogaritmalarının alınması gerekmektedir (Burkhart ve Tome, 2012). Hacim değerleri, model katsayılarının logaritmaları alınarak belirlendiği için sistematik bir hata ortaya çıkmaktadır. Bu sistematik hatanın giderilmesi için gerekli düzeltme faktörünün hesaplanması için farklı yöntemler uygulanmıştır (Burkhart ve Tome, 2012). Bu çalışmada, düzeltme faktörü hesabı için Baskerville (1972) tarafından önerilen düzeltme faktörü $\left(\frac{s e^{2}}{2}\right)$ modele eklenmiștir. Örneğin Schumacher-Hall (1933) hacim fonksiyonu için bu düzetme aşağıdaki şekilde yapılmıştır.

$$
Y=e^{\left(0.00006+1.773424 \log d+1.10086 * \log h+\frac{s e^{2}}{2}\right)}
$$

Bu formülde; $Y$, ilgili ağacin düzeltilmiş hacim değerini; $d$, ağacın göğüs çapını; $h$, ağacın toplam boyunu, se, ilgili modelin standart hatasını ve e (2.718282) doğal logaritma tabanın 1 ifade etmektedir.

En uygun hacimfonksiyonun belirlenmesinde ise; uyum indeksi $(F I)$, ortalama hata $(E)$, ortalama mutlak hata $(A A E)$ ve maksimum mutlak hata $(M A E)$, hata kareler ortalamasının karekökü (RMSE) ve Akaike bilgi kriteri (AIC) gibi altı farklı uygunluk ölçütü kullanılmıştır.

$$
\begin{aligned}
& A A E=\frac{\sum_{i=1}^{i=n}\left|y_{i}-\hat{y}_{i}\right|}{n} \\
& M A E=\max \left(\left|y_{i}-\hat{y}_{i}\right|\right) \\
& F I=1-\left[\frac{\sum_{i=1}^{n}\left(y_{i}-\hat{y}_{i}\right)^{2}}{\sum_{i=1}^{n}\left(y_{i}-\bar{y}\right)^{2}}\right]
\end{aligned}
$$

$\operatorname{RMSE}=\sqrt{\frac{\sum_{i=1}^{i=n}\left(y_{i}-\hat{y}_{i}\right)^{2}}{n-p}}$

$E=\frac{\sum_{i=1}^{i=n}\left(y_{i}-\hat{y}_{i}\right)}{n}$

$\mathrm{AIC}=n \ln (R M S E)+2 p$ 
Burada sirası ile $y_{i}, \hat{y}_{i}$ ve $\bar{y}$ ölçülen, tahmin edilen ve ölçülen değerlerin aritmetik ortalamasını ifade etmektedir. $\bar{y}_{\text {est }}$ tahmin edilen değerlerin ortalamasını, $n$ model geliştirmek için kullanılan toplam gözlem sayıs ını, $p$ geliştirilen modellerdeki parametre sayıs ını ve $\ln$ ise doğal logaritmay 1 ifade etmektedir.

$M$ tane yöntemin suralanması geleneks el olarak $1,2, \ldots$. , $\mathrm{m}$ şeklinde gösterilmektedir. Bu geleneksel sıralama biçimi, yöntemlerin sıralamasını göstermekle birlikte, yöntemler ile elde edilen sonuçların birbirine ne kadar yakın olduğu hakkında bilgi vermemektedir (Poudel ve Cao, 2013). Bu çalışmada, modellerin başarı sıralarının daha gerçekçi bir şekilde ortaya konabilmesi için Poudel ve Cao (2013) tarafindan geliştirilen nis pi sıralama yöntemi kullanılmıştır. Nispi sıralama yöntemiyle, karşılaştırılan metotların birbirine olan nispi yakılıkları hakkında bilgi edinilebilmektedir. Bir $i$ modelinin nispi siralamas1 aşağıdaki formülas yon yarımı ile bulunabilmektedir.

$$
R_{i}=1+\frac{(m-1)\left(S_{i}-S_{\min }\right)}{S_{\max }-S_{\min }}
$$

Burada,

$R_{i} \quad: i$ yönteminin nispi $\operatorname{siras} \operatorname{1n} 1(i=1,2, \ldots, m)$,

$S_{i} \quad: i$ yöntemi ile elde edilen uyum is tatistiğini,

$S_{\min } \quad$ : uyum istatistiğinin minimum değerini,

$S_{\max }$ : uyum istatistiğinin maksimum değerini ifade etmektedir.

$\mathrm{Bu}$ sıralama sisteminde, en iyi ve en kötü yöntemler sırasıyla 1 ve $m$ nispi değerini almaktadır. Kalan yöntemlerin nispi sıralama değerleri ise 1 ile $m$ arasında değişen gerçek sayılar olarak ifade edilmektedir. $S_{i}$ 'nin sıralama değerinin yanıs sra, bu değerin rakamsalbüyüklüğü de göz önünde bulundurulduğundan, bu yeni sıralama sistemi, geleneksel sıralama sistemlerine göre daha fazla bilgi sunmaktadır. Örneğin, nispi sıralamas1 1, 1.2, 4.7, 4.9 ve 5 olan beş yöntem, sözkonusu nispi sıralama sistemiyle, sıralama değerleri arasındaki büyük fark sayesinde iki ayrı gruba $(\{1,1.2\}$ ve $\{4.7,4.9,5\}$ ) ayrilabilmektedir (Poudel ve Cao, 2013).

Çalışmada, yukarıda açıklanan altı ölçüt değeri kullanılarak modellerin nisbi sıraları belirlenmiştir. Uyum indeksi dışındaki bütün ölçütler için, en küçük değere sahip olan model en iyi olarak nitelendirilmiş tir.

\section{Bulgular}

Doğal sedir meşcerelerinden alınan örnek ağaçlar kullanılarak, 30 farklı ağaç hacim denklemi için yapılan parametre tahminleri, logaritmik denklemler için düzeltme faktörleri (D.F) ve parametrelerin önem düzeyleri Çizelge 4'te verilmiştir.

Model geliştirme verileri kullanılarak, test edilen modellerin ölçüt değerleri Çizelge 5'te verilmiștir. Çok fazla modelin test edilmiş olması nedeniyle ölçüt değerlerine bağlı olarak doğrudan bir modelin diğer modellere göre daha başarılı olduğunu söylemek neredeyse imkânsızdır. Bu nedenle model geliştirme verileri için modellerin nisbi sıraları hesaplanmış ve buna ilişkin sonuçlar Çizelge 6'da verilmiştir. Çizelge 6'da ve Şekil 2'de ortaya çıkan durum değerlendirildiğinde, modelleri nisbi sıra değerlerine bağlı olarak 5 gruba ayırmak mümkündür. Birinci ve en başarılı tahminlerin yapıldı̆̆ grup 7 ve 15 nolu modellerden oluşmaktadır. 25 ve 27 nolu modeller ikinci grupta; 4, 9 ve 18 nolu modeller dördüncü grupta ve, 1, 2, 3 ve 19 nolu modeller ise beşinci ve en kötü model grubunda yer almaktadır. Diğer modeller ise üçüncü grubu oluşturmaktadır. Radar grafiğginde en içteki kutuda yer alan model ya da modeller en başarılı grubu en dışta yer alan modeller ise en başarısız grubu oluşturmaktadır. Şekil 3'te ise en başarılı ( 7 ve 15 nolu modeller) ve en başarısız ( 1 ve 2 nolu modeller) olan modellere ilişkin tahmin edilen hacim değerlerinin ölçülen hacim değerlerine göre dağılımları verilmiștir. Şekilden de görüleceği gibi başarılı olan modellerde sonuçlar, 1:1 çizgis ine çok yakın iken, başarısız modellerde noktalar, 1:1 çizgisinden oldukça ayrılmaktadır. Genel olarak tüm modellerin hata dağılımı, büyük hacim değerleri için daha yüksek bir varyans değeri göstermektedir.

Cizelge 7'de ise model test verileri kullanılarak denenen modellerin ölçüt değerlerine ilişkin sonuçlar verilmiştir. Çizelge 8'de ise her bir ölçüt değerine ve bu ölçütlerin geneline göre elde edilen nisbi suralar verilmiştir.

Şekil 4'te de altı ölçüt değerine göre test edilen modellerin radar grafiği s onuçları verilmiştir. Çizelge 8 ve Şekil 4 incelendiğinde, model test verileri için en başarılı modellerin sirasıly 7,15 ve 13 nolu modeller olduğu ve birinci grupta yer aldığ 1 görülmektedir. Model 20, 21, 25, 5, $11,17,24$ ise üçüncü grupta yer almaktadır. Model 1, 2, 3 ve 19 ise en başarısız modeller olarak dördüncü grubu oluşturmuştur. Diğer modeller ise ikinci grupta yer almaktadır. Bu sonuçlardan da görüleceği gibi, model geliştirme ve model test verileri için yapılan tüm değerlendirmelerde 7 ve 15 nolu modellerin diğ er modellere göre daha başarılı modeller olduğu görülmektedir.

Sonuç olarak; model 7 (Schumacher-Hall, 1933) gerek çok bilinen ve yaygın olarak kullanılan bir model olmas1, gerekse model 15 'e göre daha kolay kullanılabilecek bir model olması nedenleriyle Batı Akdeniz Yöresi doğal sedir meșcerelerinde tek ağaç ve buna bağlı olarak meșcere hacimlerinin tahmin edilmesi gerektiğinde kullanılabilecek bir modeldir.

Her iki veri seti içinde yapılan değerlendirmeler ışı̆̆ında, en başarılı modellerin 7 ve 15 nolu modeller olduğu görülmektedir. Bu sonuçlar ışığında, tüm veri seti için 7 ve 15 nolu modeller yeniden çözülmüş ve sirasıyla aşağıdaki katsayılar elde edilmiştir. 7 nolu model için katsayılar, $\beta_{0}=0.000063, \beta_{1}=1.752831$ ve $\beta_{2}=1.088602 ; 15$ nolu model için ise, $\beta_{0}=23540.17, \beta_{1}=157.9884$ 'dir. 7 nolu model için tüm veri seti kullanılarak elde edilen katsayılar kullanılarak Batı Akdeniz Yöresi doğal sedir meşcereleri için çift girişli ağaç hacim tablosu düzenlenmiş ve Çizelge 9'da verilmiştir. Bu çizelge kullanılarak, gögüs çap1 8-60 $\mathrm{cm}$ ve ağaç boyu $8-30 \mathrm{~m}$ arasında değişin ağaçların dikili gövde hacim değerleri $\mathrm{m}^{3}$ olarak bulunabilmektedir. 
Çizelge 4. A ğaç hacimfonksiyonlarına iliş kin parametre tahminleri

\begin{tabular}{|c|c|c|c|c|c|c|c|}
\hline \multirow{2}{*}{$\begin{array}{c}\text { Model } \\
\text { No }\end{array}$} & \multicolumn{7}{|c|}{ Katsayılar } \\
\hline & $\beta_{0}$ & $\beta_{1}$ & $\beta_{2}$ & $\beta_{3}$ & $\beta_{4}$ & $\beta_{5}$ & D.F \\
\hline 1 & $\begin{array}{c}-0.8255 \\
* * * *\end{array}$ & $\begin{array}{c}0.048992 \\
* * * *\end{array}$ & & & & & \\
\hline 2 & $\begin{array}{c}-0.9549 \\
* * * *\end{array}$ & $\begin{array}{c}0.03424 \\
* * * *\end{array}$ & $\begin{array}{c}0.03340 \\
* * * *\end{array}$ & & & & \\
\hline 3 & $\begin{array}{c}0.02542 \\
\text { NS }\end{array}$ & $\begin{array}{c}-0.01274 \\
*\end{array}$ & $\begin{array}{c}0.001022 \\
* * * *\end{array}$ & & & & \\
\hline 4 & $\begin{array}{c}0.000034 \\
* * * *\end{array}$ & & & & & & \\
\hline 5 & $\begin{array}{c}0.02354 \\
* * *\end{array}$ & $\begin{array}{c}0.000033 \\
* * * *\end{array}$ & & & & & \\
\hline 6 & $\begin{array}{c}-0.07801 \\
* *\end{array}$ & $\begin{array}{c}1.63 \times 10^{-6} \\
\mathrm{NS}\end{array}$ & $\begin{array}{c}0.008744 \\
* * * *\end{array}$ & $\begin{array}{c}0.00003 \\
* * * *\end{array}$ & & & \\
\hline 7 & $\begin{array}{c}0.00006 \\
* * * *\end{array}$ & $\begin{array}{c}1.773424 \\
* * * *\end{array}$ & $\begin{array}{c}1.100861 \\
* * * *\end{array}$ & & & & \\
\hline 8 & $\begin{array}{c}-0.0219 \\
\text { NS }\end{array}$ & $\begin{array}{l}0.00008 \\
* * * *\end{array}$ & $\begin{array}{c}1.722543 \\
* * * *\end{array}$ & $\begin{array}{c}1.066532 \\
* * * *\end{array}$ & & & \\
\hline 9 & $\underset{\text { NS }}{71.66391}$ & $\begin{array}{c}28065.27 \\
* * * *\end{array}$ & & & & & \\
\hline 10 & $\begin{array}{c}-0.02724 \\
\text { NS }\end{array}$ & $\begin{array}{c}0.00032 \\
* *\end{array}$ & $\begin{array}{c}2.421576 \\
* * * *\end{array}$ & $\begin{array}{c}-0.00026 \\
\text { NS }\end{array}$ & $\begin{array}{c}3.118315 \\
* * * *\end{array}$ & & \\
\hline 11 & $\begin{array}{c}0.22993 \\
\text { NS }\end{array}$ & $\begin{array}{c}-0.01384 \\
\text { NS }\end{array}$ & $\begin{array}{c}0.000136 \\
\text { NS }\end{array}$ & $\begin{array}{c}-0.02498 \\
* *\end{array}$ & $\begin{array}{c}0.00173 \\
* * *\end{array}$ & $\begin{array}{c}9.30 \times 10^{-6} \\
\mathrm{NS}\end{array}$ & \\
\hline 12 & $\begin{array}{c}-0.0371 \\
\text { NS }\end{array}$ & $\begin{array}{c}0.000345 \\
* * * *\end{array}$ & $\begin{array}{c}-0.00026 \\
\text { NS }\end{array}$ & $\begin{array}{c}0.000033 \\
*\end{array}$ & $\begin{array}{c}1.92 \times 10^{-1} \\
*\end{array}$ & & \\
\hline 13 & $\begin{array}{c}0.01845 \\
* *\end{array}$ & $\begin{array}{c}0.00004 \\
* * * *\end{array}$ & $\begin{array}{c}0.159969 \\
* * * *\end{array}$ & & & & \\
\hline 14 & $\begin{array}{c}-0.0772 \\
* * * *\end{array}$ & $\begin{array}{c}0.00003 \\
* * * *\end{array}$ & $\begin{array}{c}0.008709 \\
* * * * *\end{array}$ & & & & \\
\hline 15 & $\begin{array}{c}24190.31 \\
* * * *\end{array}$ & $\begin{array}{c}136.8592 \\
* * * *\end{array}$ & & & & & \\
\hline 16 & $\begin{array}{c}0.009035 \\
\text { NS }\end{array}$ & $\begin{array}{c}0.00034 \\
* * * *\end{array}$ & $\begin{array}{c}8.05 \times 10^{-1} \\
* * * *\end{array}$ & & & & \\
\hline 17 & $\begin{array}{c}-0.19473 \\
* * * *\end{array}$ & $\begin{array}{c}0.015114 \\
* * * *\end{array}$ & $\begin{array}{c}0.00006 \\
\text { NS }\end{array}$ & $\begin{array}{c}8.60 \times 10^{-1} \\
* * * *\end{array}$ & & & \\
\hline 18 & $\begin{array}{c}0.00003 \\
* * * *\end{array}$ & $\begin{array}{c}0.000032 \\
* * * *\end{array}$ & & & & & \\
\hline 19 & $\begin{array}{c}-0.15584 \\
* * * *\end{array}$ & $\begin{array}{c}0.00082 \\
* * * *\end{array}$ & & & & & \\
\hline 20 & $\begin{array}{c}-0.00008 \\
\text { NS }\end{array}$ & $\begin{array}{c}0.000041 \\
* * * *\end{array}$ & $\begin{array}{c}5.27 \times 10^{-7} \\
* *\end{array}$ & $\begin{array}{c}0.000083 \\
\text { NS }\end{array}$ & $\begin{array}{c}0.000018 \\
\text { NS }\end{array}$ & & \\
\hline 21 & $\begin{array}{c}-0.1429 \\
* * * *\end{array}$ & $\begin{array}{c}0.013586 \\
* * * *\end{array}$ & $\begin{array}{c}0.000328 \\
* * * *\end{array}$ & $\begin{array}{c}0.00004 \\
* * * *\end{array}$ & & & \\
\hline 22 & $\begin{array}{c}0.060823 \\
\text { NS }\end{array}$ & $\begin{array}{c}0.000052 \\
* * * *\end{array}$ & $\begin{array}{c}-2.8 \times 10^{-7} \\
* * * *\end{array}$ & $\begin{array}{c}-9.8 \times 10^{-\gamma} \\
*\end{array}$ & $\begin{array}{c}-0.0055 \\
\text { NS }\end{array}$ & & \\
\hline 23 & $\begin{array}{c}-0.00096 \\
\text { NS }\end{array}$ & $\begin{array}{c}0.000042 \\
* * * *\end{array}$ & $\begin{array}{c}-2.5 \times 10^{-1} \\
* * *\end{array}$ & $\begin{array}{c}1.29 \times 10^{-1} \\
\mathrm{NS}\end{array}$ & $\begin{array}{c}-0.00121 \\
\text { NS }\end{array}$ & & \\
\hline 24 & $\begin{array}{c}-0.12352 \\
* * * *\end{array}$ & $\begin{array}{c}0.001464 \\
* * * *\end{array}$ & $\begin{array}{c}-0.00004 \\
\quad * * * *\end{array}$ & $\begin{array}{c}9.78 \times 10^{-1} \\
* * * *\end{array}$ & & & \\
\hline 25 & $\begin{array}{c}-0.23839 \\
* * * *\end{array}$ & $\begin{array}{c}0.017774 \\
* * * *\end{array}$ & $\begin{array}{c}5.11 \times 10^{-6} \\
\mathrm{NS}\end{array}$ & $\begin{array}{c}7.75 \times 10^{-7} \\
* * * *\end{array}$ & & & \\
\hline 26 & $\begin{array}{c}-9,98869 \\
* * * *\end{array}$ & $\begin{array}{c}1,86939 \\
* * * *\end{array}$ & $\begin{array}{c}1,056201 \\
* * * *\end{array}$ & & & & 0.0044 \\
\hline 27 & $\begin{array}{c}-9.96731 \\
* * * *\end{array}$ & $\begin{array}{c}2.75324 \\
* * * *\end{array}$ & $\begin{array}{c}-0.13174 \\
*\end{array}$ & $\begin{array}{c}-0.0186 \\
\text { NS }\end{array}$ & $\begin{array}{c}0.191708 \\
* *\end{array}$ & & 0.0043 \\
\hline 28 & $\begin{array}{c}-10.132 \\
* * * *\end{array}$ & $\begin{array}{c}1.92447 \\
* * * *\end{array}$ & $\begin{array}{c}1.053016 \\
* * * *\end{array}$ & $\begin{array}{c}-0.00003 \\
\text { NS }\end{array}$ & & & 0.0044 \\
\hline 29 & $\begin{array}{c}-10.0519 \\
* * * *\end{array}$ & $\begin{array}{c}1.88481 \\
* * * *\end{array}$ & $\begin{array}{c}1.064076 \\
* * * *\end{array}$ & $\begin{array}{c}-5.62 \mathrm{E}-7 \\
\mathrm{NS}\end{array}$ & & & 0.0044 \\
\hline 30 & $\begin{array}{c}-9.97642 \\
* * * *\end{array}$ & $\begin{array}{c}1.868231 \\
* * * *\end{array}$ & $\begin{array}{c}1.052429 \\
* * * *\end{array}$ & $\begin{array}{c}2.03 \mathrm{E}-7 \\
\mathrm{NS}\end{array}$ & & & 0.0044 \\
\hline
\end{tabular}


Diğer taraftan, ilgi model ile elde edilen sonuçlar, Evcimen (1963) tarafindan geliştirilen çift girişli ağaç hacim denklemi sonuçları ile bağımsız veri seti kullanılarak karşılaştırılmıştır. Şekil 5'ten de görüleceği gibi her iki model de, özellikle $10-20 \mathrm{~cm}$ arasındaki gögüs çap1 değerleri için oldukça yakın sonuçlar üretmiştir. Ancak, özellikle $30 \mathrm{~cm}$ ve daha yukarı göğüs çapı değerleri için Evcimen (1963) tarafindan geliştirilen modelin daha yüksek hacim hatası değerleri ürettiğgive buna bağlı olarak da daha yüksek hata varyans ına sahip oldukları söylenebilir.

Sedir ağaç türü için elde edilen en başarılı model olan Schumacher-Hall (1933) modelinin, bölgesel olarak kullanılabilirliğinin denetimi için, kontrol verileri kullanılarak yapılan "Eşlendirilmiş $t$-testi” sonuçlarına göre de, geliştirilen hacim denkleminin $\mathrm{p}>0.05$ önem düzeyinde güvenle kullanılabileceği sonucuna varılmıştır.

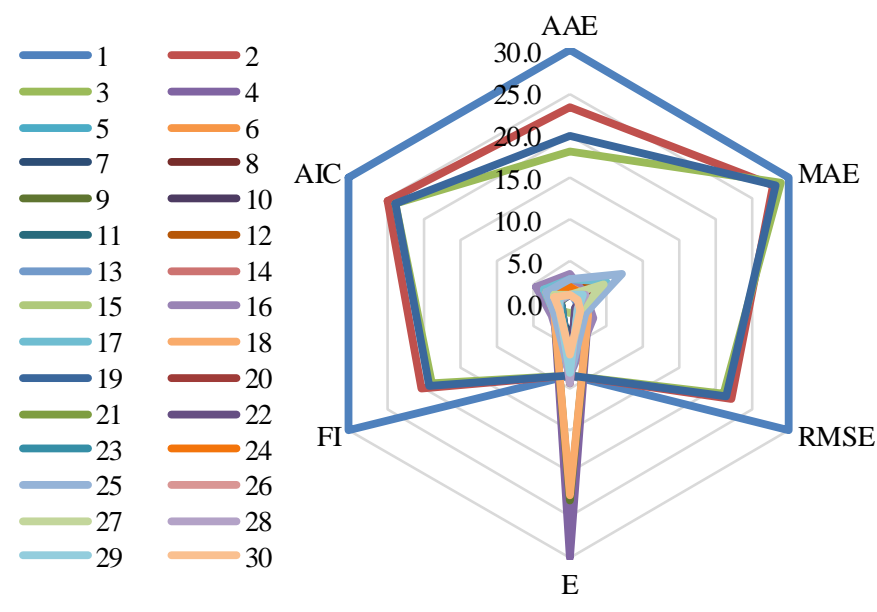

Şekil 2. Model geliştirme verileri için modellerin altı ölçüte göre rölatif s ıralarının radar grafiği

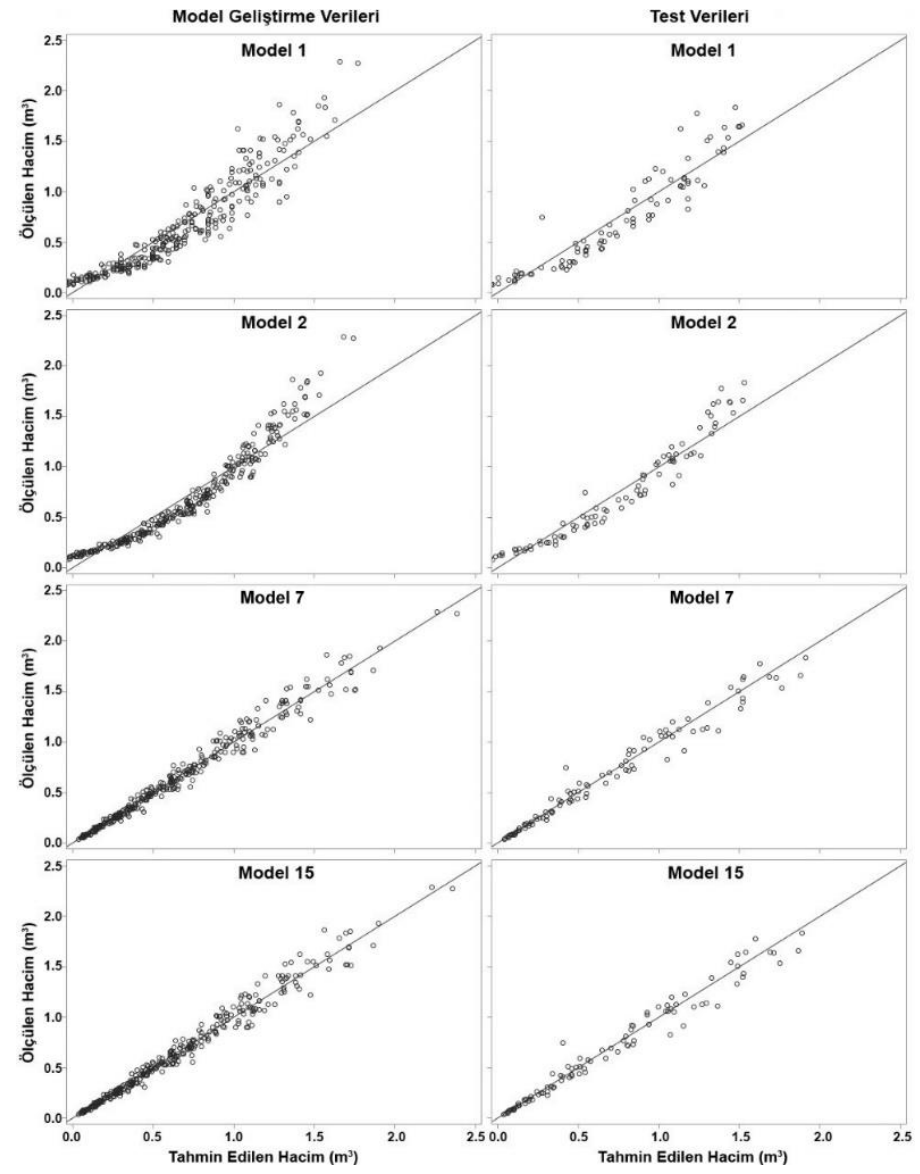

Şekil 3. En başarılı (7 ve 15) ve en başarısız (1 ve 2) modeller için ölçülen hacim değerlerine karşı tahmin edilen hacimlerin dağılımı 

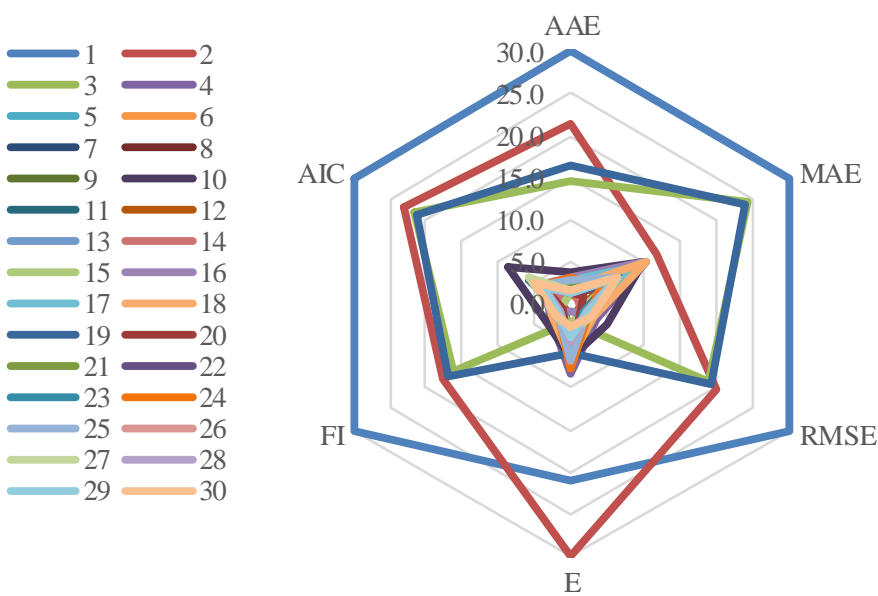

Şekil 4. Model test verileri için modellerin altı ölçüte göre rölatif sıralarının radar grafiği

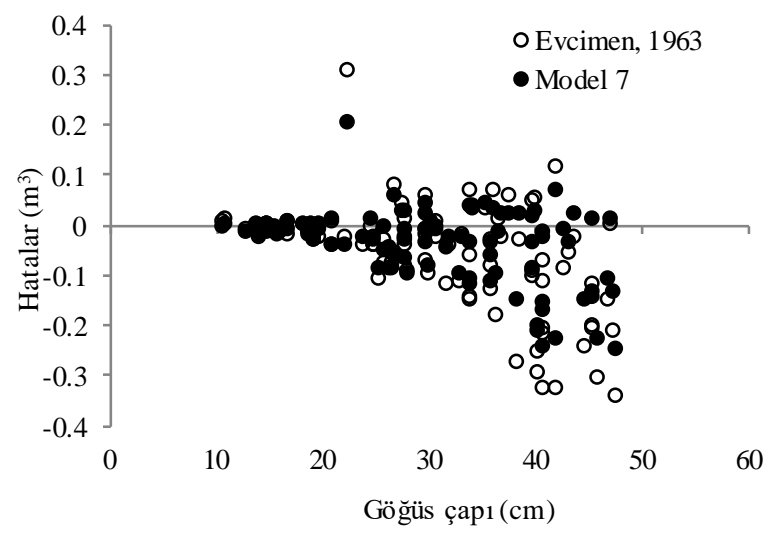

Şekil 5. İki farkı hacim denklemi ile elde edilen sonuçlarının karşılaştırılması

Çizelge 5. Model geliştirme verileri için elde edilen ölçüt değerleri

\begin{tabular}{|c|c|c|c|c|c|c|}
\hline Model No & AAE & MAE & RMSE & $E$ & FI & AIC \\
\hline 1 & 0.1263 & 0.6320 & 0.1628 & 0.0000 & 0.8784 & -596.9211 \\
\hline 2 & 0.1079 & 0.6077 & 0.1376 & 0.0000 & 0.9133 & -650.4371 \\
\hline 3 & 0.0922 & 0.6180 & 0.1339 & 0.0000 & 0.9179 & -659.5014 \\
\hline 4 & 0.0473 & 0.2813 & 0.0719 & 0.0085 & 0.9762 & -869.2036 \\
\hline 5 & 0.0473 & 0.2936 & 0.0706 & 0.0000 & 0.9771 & -873.2452 \\
\hline 6 & 0.0453 & 0.2941 & 0.0679 & 0.0000 & 0.9789 & -882.1123 \\
\hline 7 & 0.0444 & 0.2857 & 0.0672 & -0.0017 & 0.9793 & -887.5259 \\
\hline 8 & 0.0445 & 0.2891 & 0.0671 & 0.0000 & 0.9795 & -886.3461 \\
\hline 9 & 0.0468 & 0.2925 & 0.0717 & 0.0058 & 0.9764 & -868.1636 \\
\hline 10 & 0.0471 & 0.2938 & 0.0691 & 0.0000 & 0.9783 & -874.6333 \\
\hline 11 & 0.0440 & 0.2868 & 0.0668 & 0.0000 & 0.9798 & -883.6097 \\
\hline 12 & 0.0458 & 0.3185 & 0.0688 & 0.0000 & 0.9785 & -876.1430 \\
\hline 13 & 0.0450 & 0.2724 & 0.0682 & 0.0000 & 0.9787 & -882.7907 \\
\hline 14 & 0.0453 & 0.2938 & 0.0678 & 0.0000 & 0.9789 & -884.6163 \\
\hline 15 & 0.0454 & 0.3024 & 0.0676 & -0.0030 & 0.9790 & -887.5914 \\
\hline 16 & 0.0511 & 0.2890 & 0.0745 & 0.0000 & 0.9746 & -853.6080 \\
\hline 17 & 0.0497 & 0.3248 & 0.0716 & 0.0000 & 0.9766 & -864.9145 \\
\hline 18 & 0.0468 & 0.2900 & 0.0718 & 0.0056 & 0.9764 & -867.9302 \\
\hline 19 & 0.0976 & 0.6108 & 0.1350 & 0.0000 & 0.9163 & -658.7347 \\
\hline 20 & 0.0442 & 0.2967 & 0.0670 & 0.0003 & 0.9796 & -884.4938 \\
\hline 21 & 0.0453 & 0.2825 & 0.0678 & 0.0000 & 0.9790 & -882.9303 \\
\hline 22 & 0.0441 & 0.2886 & 0.0668 & 0.0000 & 0.9797 & -885.7789 \\
\hline 23 & 0.0444 & 0.2850 & 0.0670 & 0.0000 & 0.9796 & -884.5543 \\
\hline 24 & 0.0472 & 0.2840 & 0.0691 & 0.0000 & 0.9782 & -876.6544 \\
\hline 25 & 0.0492 & 0.3515 & 0.0713 & 0.0000 & 0.9768 & -865.9703 \\
\hline 26 & 0.0446 & 0.2746 & 0.0683 & -0.0009 & 0.9787 & -882.5021 \\
\hline 27 & 0.0442 & 0.3177 & 0.0685 & -0.0008 & 0.9787 & -877.5027 \\
\hline 28 & 0.0443 & 0.2868 & 0.0673 & 0.0003 & 0.9793 & -885.2888 \\
\hline 29 & 0.0443 & 0.2842 & 0.0676 & -0.0002 & 0.9791 & -883.5452 \\
\hline 30 & 0.0447 & 0.2740 & 0.0685 & -0.0010 & 0.9786 & -879.2667 \\
\hline
\end{tabular}


Çizelge 6. Model geliştirme verileri ve modeller için nis bi sıralama sonuçları

\begin{tabular}{|c|c|c|c|c|c|c|c|c|}
\hline \multirow{2}{*}{$\begin{array}{c}\text { Model } \\
\text { No }\end{array}$} & \multicolumn{6}{|c|}{ Nispi Siralama } & \multirow{2}{*}{ Sira Toplamları } & \multirow{2}{*}{ Genel Siralama } \\
\hline & AAE & MAE & RMSE & $\mathrm{E}$ & FI & $\mathrm{AIC}$ & & \\
\hline 1 & 30.000 & 30.000 & 30.000 & 8.590 & 30.000 & 30.000 & 158.590 & 30.000 \\
\hline 2 & 23.498 & 28.036 & 22.406 & 8.590 & 20.009 & 24.661 & 127.199 & 23.899 \\
\hline 3 & 17.986 & 28.866 & 21.283 & 8.590 & 18.687 & 23.756 & 119.168 & 22.338 \\
\hline 4 & 2.164 & 1.713 & 2.555 & 30.000 & 2.024 & 2.835 & 41.290 & 7.204 \\
\hline 5 & 2.136 & 2.709 & 2.162 & 8.590 & 1.759 & 2.431 & 19.788 & 3.025 \\
\hline 6 & 1.443 & 2.751 & 1.348 & 8.590 & 1.232 & 1.547 & 16.911 & 2.466 \\
\hline 7 & 1.136 & 2.071 & 1.138 & 4.421 & 1.128 & 1.007 & 10.900 & 1.298 \\
\hline 8 & 1.175 & 2.347 & 1.088 & 8.589 & 1.080 & 1.124 & 15.404 & 2.173 \\
\hline 9 & 1.977 & 2.619 & 2.492 & 23.177 & 1.964 & 2.938 & 35.168 & 6.014 \\
\hline 10 & 2.080 & 2.726 & 1.691 & 8.590 & 1.416 & 2.293 & 18.795 & 2.832 \\
\hline 11 & 1.000 & 2.157 & 1.010 & 8.590 & 1.000 & 1.397 & 15.154 & 2.125 \\
\hline 12 & 1.620 & 4.716 & 1.596 & 8.590 & 1.360 & 2.142 & 20.025 & 3.071 \\
\hline 13 & 1.353 & 1.000 & 1.431 & 8.590 & 1.299 & 1.479 & 15.152 & 2.124 \\
\hline 14 & 1.436 & 2.725 & 1.317 & 8.590 & 1.233 & 1.297 & 16.597 & 2.405 \\
\hline 15 & 1.473 & 3.419 & 1.257 & 1.000 & 1.215 & 1.000 & 9.364 & 1.000 \\
\hline 16 & 3.477 & 2.335 & 3.330 & 8.590 & 2.474 & 4.391 & 24.596 & 3.960 \\
\hline 17 & 2.989 & 5.220 & 2.443 & 8.590 & 1.892 & 3.262 & 24.397 & 3.921 \\
\hline 18 & 1.990 & 2.421 & 2.508 & 22.716 & 1.973 & 2.962 & 34.570 & 5.898 \\
\hline 19 & 19.872 & 28.283 & 21.622 & 8.590 & 19.156 & 23.833 & 121.356 & 22.764 \\
\hline 20 & 1.059 & 2.960 & 1.079 & 9.335 & 1.057 & 1.309 & 16.799 & 2.444 \\
\hline 21 & 1.437 & 1.815 & 1.298 & 8.590 & 1.203 & 1.465 & 15.808 & 2.252 \\
\hline 22 & 1.019 & 2.305 & 1.000 & 8.590 & 1.012 & 1.181 & 15.106 & 2.116 \\
\hline 23 & 1.115 & 2.013 & 1.075 & 8.590 & 1.055 & 1.303 & 15.151 & 2.124 \\
\hline 24 & 2.130 & 1.937 & 1.690 & 8.590 & 1.434 & 2.091 & 17.872 & 2.653 \\
\hline 25 & 2.827 & 7.380 & 2.374 & 8.590 & 1.850 & 3.157 & 26.178 & 4.267 \\
\hline 26 & 1.198 & 1.173 & 1.449 & 6.378 & 1.310 & 1.508 & 13.014 & 1.709 \\
\hline 27 & 1.073 & 4.648 & 1.511 & 6.559 & 1.310 & 2.007 & 17.107 & 2.504 \\
\hline 28 & 1.081 & 2.161 & 1.152 & 9.237 & 1.118 & 1.230 & 15.979 & 2.285 \\
\hline 29 & 1.098 & 1.948 & 1.260 & 8.038 & 1.181 & 1.404 & 14.927 & 2.081 \\
\hline 30 & 1.224 & 1.123 & 1.526 & 6.054 & 1.337 & 1.831 & 13.094 & 1.724 \\
\hline
\end{tabular}

Çizelge 7. Model test verileri için elde edilen ölçüt değerleri

\begin{tabular}{|c|c|c|c|c|c|c|}
\hline $\begin{array}{l}\text { Model } \\
\text { No }\end{array}$ & AAE & MAE & RMSE & $\mathrm{E}$ & FI & AIC \\
\hline 1 & 0.1410 & 0.5413 & 0.1755 & 0.0097 & 0.8814 & -166.5545 \\
\hline 2 & 0.1166 & 0.3900 & 0.1458 & 0.0208 & 0.9189 & -182.6854 \\
\hline 3 & 0.0968 & 0.4924 & 0.1418 & -0.0136 & 0.9233 & -185.4353 \\
\hline 4 & 0.0618 & 0.3762 & 0.0961 & -0.0060 & 0.9641 & -227.5723 \\
\hline 5 & 0.0625 & 0.3616 & 0.0935 & -0.0133 & 0.9663 & -228.2873 \\
\hline 6 & 0.0608 & 0.3008 & 0.0899 & -0.0086 & 0.9695 & -228.1154 \\
\hline 7 & 0.0599 & 0.3257 & 0.0901 & -0.0113 & 0.9690 & -229.8723 \\
\hline 8 & 0.0596 & 0.3260 & 0.0901 & -0.0087 & 0.9693 & -227.8288 \\
\hline 9 & 0.0613 & 0.3761 & 0.0953 & -0.0081 & 0.9650 & -226.3509 \\
\hline 10 & 0.0667 & 0.3742 & 0.1003 & -0.0085 & 0.9624 & -215.3460 \\
\hline 11 & 0.0592 & 0.3548 & 0.0922 & -0.0099 & 0.9686 & -221.6141 \\
\hline 12 & 0.0585 & 0.3349 & 0.0888 & -0.0092 & 0.9705 & -227.2401 \\
\hline 13 & 0.0625 & 0.3300 & 0.0924 & -0.0113 & 0.9674 & -227.3998 \\
\hline 14 & 0.0609 & 0.3008 & 0.0894 & -0.0087 & 0.9695 & -230.5994 \\
\hline 15 & 0.0589 & 0.3439 & 0.0893 & -0.0130 & 0.9693 & -232.7282 \\
\hline 16 & 0.0648 & 0.3759 & 0.0954 & -0.0152 & 0.9653 & -224.2461 \\
\hline 17 & 0.0635 & 0.3663 & 0.0932 & -0.0102 & 0.9672 & -224.5578 \\
\hline 18 & 0.0611 & 0.3766 & 0.0952 & -0.0084 & 0.9650 & -226.4316 \\
\hline 19 & 0.1029 & 0.4908 & 0.1431 & -0.0091 & 0.9211 & -186.5129 \\
\hline 20 & 0.0589 & 0.3077 & 0.0897 & -0.0083 & 0.9700 & -226.2829 \\
\hline 21 & 0.0617 & 0.3414 & 0.0923 & -0.0089 & 0.9679 & -225.5269 \\
\hline 22 & 0.0591 & 0.3316 & 0.0911 & -0.0098 & 0.9690 & -224.7447 \\
\hline 23 & 0.0589 & 0.3449 & 0.0911 & -0.0096 & 0.9690 & -224.7711 \\
\hline 24 & 0.0644 & 0.3281 & 0.0925 & -0.0069 & 0.9677 & -225.3159 \\
\hline 25 & 0.0641 & 0.3460 & 0.0924 & -0.0079 & 0.9678 & -225.4116 \\
\hline 26 & 0.0603 & 0.3456 & 0.0937 & -0.0128 & 0.9666 & -226.0818 \\
\hline 27 & 0.0604 & 0.3438 & 0.0944 & -0.0124 & 0.9667 & -221.2721 \\
\hline 28 & 0.0592 & 0.3450 & 0.0914 & -0.0105 & 0.9685 & -226.4223 \\
\hline 29 & 0.0595 & 0.3444 & 0.0923 & -0.0114 & 0.9678 & -225.4684 \\
\hline 30 & 0.0605 & 0.3459 & 0.0945 & -0.0131 & 0.9663 & -223.2121 \\
\hline
\end{tabular}


Çizelge 8. Model test verilerive test edilen modeller için nisbi sıralama sonuçları

\begin{tabular}{|c|c|c|c|c|c|c|c|c|}
\hline \multirow{2}{*}{ Model No } & \multicolumn{6}{|c|}{ Nispi Siralama } & \multirow{2}{*}{ Siralamalar Toplamı } & \multirow{2}{*}{ Genel Siralama } \\
\hline & AAE & MAE & RMSE & $\mathrm{E}$ & FI & AIC & & \\
\hline 1 & 30.000 & 30.000 & 30.000 & 21.009 & 30.000 & 30.000 & 171.009 & 30.000 \\
\hline 2 & 21.435 & 11.759 & 20.077 & 30.000 & 17.789 & 22.931 & 123.991 & 21.341 \\
\hline 3 & 14.470 & 24.105 & 18.726 & 2.280 & 16.350 & 21.726 & 97.656 & 16.492 \\
\hline 4 & 2.174 & 10.091 & 3.421 & 8.391 & 3.106 & 3.260 & 30.443 & 4.114 \\
\hline 5 & 2.394 & 8.330 & 2.542 & 2.458 & 2.362 & 2.946 & 21.031 & 2.381 \\
\hline 6 & 1.826 & 1.004 & 1.343 & 6.259 & 1.328 & 3.022 & 14.782 & 1.230 \\
\hline 7 & 1.493 & 3.999 & 1.418 & 4.135 & 1.483 & 2.252 & 14.780 & 1.229 \\
\hline 8 & 1.403 & 4.034 & 1.432 & 6.168 & 1.386 & 3.147 & 17.570 & 1.743 \\
\hline 9 & 1.971 & 10.082 & 3.167 & 6.703 & 2.803 & 3.795 & 28.520 & 3.760 \\
\hline 10 & 3.879 & 9.851 & 4.839 & 6.390 & 3.633 & 8.618 & 37.210 & 5.360 \\
\hline 11 & 1.243 & 7.510 & 2.121 & 5.244 & 1.625 & 5.871 & 23.614 & 2.857 \\
\hline 12 & 1.000 & 5.115 & 1.000 & 5.802 & 1.000 & 3.405 & 17.322 & 1.698 \\
\hline 13 & 2.424 & 4.526 & 2.189 & 4.151 & 2.004 & 3.335 & 18.630 & 1.939 \\
\hline 14 & 1.829 & 1.000 & 1.195 & 6.241 & 1.335 & 1.933 & 13.533 & 1.000 \\
\hline 15 & 1.147 & 6.198 & 1.156 & 2.777 & 1.413 & 1.000 & 13.691 & 1.029 \\
\hline 16 & 3.209 & 10.064 & 3.201 & 1.000 & 2.708 & 4.717 & 24.899 & 3.093 \\
\hline 17 & 2.745 & 8.895 & 2.456 & 4.965 & 2.074 & 4.581 & 25.716 & 3.244 \\
\hline 18 & 1.927 & 10.137 & 3.140 & 6.420 & 2.784 & 3.759 & 28.168 & 3.695 \\
\hline 19 & 16.603 & 23.916 & 19.175 & 5.904 & 17.091 & 21.253 & 103.942 & 17.649 \\
\hline 20 & 1.140 & 1.833 & 1.292 & 6.496 & 1.189 & 3.825 & 15.775 & 1.413 \\
\hline 21 & 2.134 & 5.901 & 2.149 & 6.031 & 1.866 & 4.156 & 22.236 & 2.603 \\
\hline 22 & 1.215 & 4.720 & 1.767 & 5.358 & 1.501 & 4.499 & 19.060 & 2.018 \\
\hline 23 & 1.159 & 6.319 & 1.759 & 5.455 & 1.495 & 4.487 & 20.674 & 2.315 \\
\hline 24 & 3.073 & 4.292 & 2.215 & 7.689 & 1.911 & 4.248 & 23.429 & 2.822 \\
\hline 25 & 2.959 & 6.448 & 2.185 & 6.883 & 1.890 & 4.206 & 24.572 & 3.033 \\
\hline 26 & 1.643 & 6.404 & 2.608 & 2.901 & 2.293 & 3.913 & 19.762 & 2.147 \\
\hline 27 & 1.686 & 6.183 & 2.868 & 3.239 & 2.241 & 6.021 & 22.238 & 2.603 \\
\hline 28 & 1.252 & 6.327 & 1.868 & 4.744 & 1.677 & 3.764 & 19.631 & 2.123 \\
\hline 29 & 1.356 & 6.262 & 2.167 & 3.996 & 1.878 & 4.182 & 19.842 & 2.162 \\
\hline 30 & 1.699 & 6.442 & 2.887 & 2.693 & 2.371 & 5.170 & 21.263 & 2.423 \\
\hline
\end{tabular}

Çizelge 9. Batı Akdeniz Yöresi sedir meşcereleri için çift girişli hacim tablosu $\left(\mathrm{m}^{3}\right)$

\begin{tabular}{|c|c|c|c|c|c|c|c|c|c|c|c|c|}
\hline \multirow{2}{*}{$\begin{array}{l}\text { Çap } \\
\text { (cm) }\end{array}$} & \multicolumn{12}{|c|}{ Ağaç boyu (m) } \\
\hline & 8 & 10 & 12 & 14 & 16 & 18 & 20 & 22 & 24 & 26 & 28 & 30 \\
\hline 8 & 0.0232 & & & & & & & & & & & \\
\hline 10 & 0.0343 & 0.0437 & & & & & & & & & & \\
\hline 12 & 0.0472 & 0.0602 & 0.0734 & & & & & & & & & \\
\hline 14 & 0.0619 & 0.0789 & 0.0962 & 0.1138 & & & & & & & & \\
\hline 16 & 0.0782 & 0.0997 & 0.1216 & 0.1438 & 0.1663 & & & & & & & \\
\hline 18 & & 0.1338 & 0.1494 & 0.1767 & 0.2044 & & & & & & & \\
\hline 20 & & 0.1612 & 0.1797 & 0.2126 & 0.2458 & 0.2795 & & & & & & \\
\hline 22 & & & 0.2124 & 0.2512 & 0.2905 & 0.3303 & & & & & & \\
\hline 24 & & & 0.2474 & 0.2926 & 0.3384 & 0.3847 & & & & & & \\
\hline 26 & & & 0.2847 & 0.3367 & 0.3894 & 0.4426 & & & & & & \\
\hline 28 & & & 0.3242 & 0.3834 & 0.4434 & 0.5040 & 0.5653 & 0.6271 & 0.6894 & & & \\
\hline 30 & & & & 0.4327 & 0.5004 & 0.5688 & 0.6380 & 0.7077 & 0.7780 & & & \\
\hline 32 & & & & & 0.5603 & 0.6370 & 0.7144 & 0.7925 & 0.8712 & 0.9505 & 1.0304 & \\
\hline 34 & & & & & & 0.7084 & 0.7945 & 0.8813 & 0.9689 & 1.0571 & 1.1459 & \\
\hline 36 & & & & & & 0.7830 & 0.8782 & 0.9742 & 1.0710 & 1.1685 & 1.2666 & \\
\hline 38 & & & & & & 0.8608 & 0.9655 & 1.0710 & 1.1774 & 1.2846 & 1.3926 & 1.5012 \\
\hline 40 & & & & & & 0.9418 & 1.0563 & 1.1718 & 1.2882 & 1.4055 & 1.5236 & 1.6424 \\
\hline 42 & & & & & & 1.0259 & 1.1506 & 1.2764 & 1.4032 & 1.5310 & 1.6596 & 1.7890 \\
\hline 44 & & & & & & 1.1131 & 1.2484 & 1.3848 & 1.5224 & 1.6610 & 1.8006 & 1.9410 \\
\hline 46 & & & & & & 1.2033 & 1.3495 & 1.4971 & 1.6458 & 1.7956 & 1.9465 & 2.0983 \\
\hline 48 & & & & & & 1.2965 & 1.4540 & 1.6130 & 1.7733 & 1.9347 & 2.0973 & 2.2608 \\
\hline 50 & & & & & & 1.3926 & 1.5619 & 1.7327 & 1.9048 & 2.0782 & 2.2528 & 2.4285 \\
\hline 52 & & & & & & 1.4918 & 1.6730 & 1.8560 & 2.0404 & 2.2261 & 2.4131 & 2.6014 \\
\hline 54 & & & & & & 1.5938 & 1.7875 & 1.9829 & 2.1799 & 2.3784 & 2.5782 & 2.7793 \\
\hline 56 & & & & & & 1.6987 & 1.9051 & 2.1134 & 2.3234 & 2.5349 & 2.7479 & 2.9622 \\
\hline 58 & & & & & & & 2.0260 & 2.2475 & 2.4708 & 2.6957 & 2.9222 & 3.1501 \\
\hline 60 & & & & & & & 2.1500 & 2.3851 & 2.6220 & 2.8608 & 3.1011 & 3.3430 \\
\hline 62 & & & & & & & 2.2772 & 2.5262 & 2.7772 & 3.0300 & 3.2846 & 3.5408 \\
\hline 64 & & & & & & & 2.4075 & 2.6707 & 2.9361 & 3.2034 & 3.4725 & 3.7434 \\
\hline 66 & & & & & & & & 2.8188 & 3.0988 & 3.3809 & 3.6650 & 3.9509 \\
\hline 68 & & & & & & & & 2.9702 & 3.2653 & 3.5626 & 3.8619 & 4.1631 \\
\hline 70 & & & & & & & & 3.1250 & 3.4355 & 3.7482 & 4.0632 & 4.3801 \\
\hline 72 & & & & & & & & 3.2832 & 3.6094 & 3.9380 & 4.2688 & 4.6018 \\
\hline 74 & & & & & & & & 3.6095 & 3.9682 & 4.3294 & 4.6932 & 5.0592 \\
\hline 76 & & & & & & & & 3.7777 & 4.1530 & 4.5311 & 4.9118 & 5.2949 \\
\hline 78 & & & & & & & & 3.9491 & 4.3415 & 4.7367 & 5.1347 & 5.5352 \\
\hline 80 & & & & & & & & 3.9491 & 4.3415 & 4.7367 & 5.1347 & 5.5352 \\
\hline
\end{tabular}




\section{Sonuçlar ve öneriler}

$\mathrm{Bu}$ çalışmada; Batı Akdeniz yöresi doğal sedir meşcereleri için hacim denklemleri geliştirilmiştir. $\mathrm{Bu}$ amaçla seçilen farklı formlardaki 30 adet hacim denklemi, altı farklı ölçüt değeri kullanılarak test edilmiştir. Yörede 429 örnek ağaç ölçülmüss, bu ağaçların tesadüfi olarak yaklaşık \%75'i (329 ağaç) model geliştirmek ve geri kalan yaklaşık \%25'lik kısım (98 ağaç) ise geliştirilen modellerin test edilmesi için kullanılmıştır. Yapılan istatistiksel değerlendirmeler sonucunda, gerek model geliştirme verisi, gerekse de model test verileri için en başarılı sonuçlar 7 (Schumacher-Hall, 1933) ve 15 (Takata, 1958) nolu modeller ile elde edilmiştir. Benzer sonuçlar tüm veri setin için yapılan değerlendirmelerde de ortaya çıkmıştır.

Ancak 7 nolu model; yaygın olarak kullanılması, çok bilinen bir model olması, bu model yardımı ile ağaç hacim tahminlerinin daha kolay yapılabilir olması ve diğer çalışmalarda elde edilen sonuçlarla karșılaștırma yapılabilme imkânı sağlaması nedeniyle 15 nolu modele tercih edilmiş tir. Geliştirilen ve yörede kullanılması önerilen ağaç hacim denkleminin yöresel olarak kullanılabilirliğinin denetimi için kontrol verileri ile gerçekleştirilen denetimler sonucunda bu modelin ilgili ağaç türü için gövde hacim tahminlerinde güvenle kullanılabileceği sonucuna varılmıştır. Sedir ağaç türü için geliştirilen ve önerilen ağaç hacim denkleminin ilgili yörede ağaç hacim tahminlerinde kullanılabilmesi için, ağaç boyunun ve gögüs yüksekliği çapının ölçülmesi yeterli olacaktır. Bu değerler ilgili ağaç hacim denkleminde yerine konularak ağaç gövde hacmi $\mathrm{m}^{3}$ olarak hesaplanabilir. Örneğin $47 \mathrm{~cm}$ gögüus çapına ve $19 \mathrm{~m}$ boya sahip bir sedir ağacının gövde hacmini bulmak is tendiğinde, en uygun model olan 7 nolu modelin tüm veri seti için elde edilen katsayıları, ilgili ağacın göğüs çapı ve boy değerleri ilgili denklemde yerine konarak gövde hacmi $\mathrm{m}^{3}$ olarak tahmin edilmelidir. $\mathrm{Bu}$ amaçla aşağıdaki işlemin yapılması yeterlidir. $\mathrm{Bu}$ işlem ile gövde hacmi $V=0.00006 * 47^{1.752831} * 19^{1.088602}=1.3253 \mathrm{~m}^{3}$ olarak bulunur.

Calışmada geliștirilen ve sedir ağaç hacim tahminleri için önerilen 7 nolu hacim denklemi ile ilgili ağaç türü için Evcimen (1963) tarafindan geliștirilen çift girişli hacim denklemi karşılaştırılmış ve Evcimen (1963) denkleminin daha yüksek hacim hatas1 verdiği görülmüştür. Özellikle hata miktarı kalın çap sınıflarında daha da yüks ektir.

Sonuç olarak; Schumacher-Hall (1933) modeli ve elde edilen katsayılar kullanılarak, Batı Akdeniz Yöresi doğal sedir meşcereleri için ağaç hacim değerleri gerçeğe yakın bir şekilde tahmin edilebilir. Ancak genel bir kural olarak, imkânlar el verdiği ölçüde ve yeterli miktarda örnek ağaç ölçümü yapılabildiği sürece her yöre ve ağaç türü için ayrı hacim fonksiyonlarının geliştirilmesi gerçeğe daha yakın hacim tahminleri yapılabilmesi için daha yararlı olacaktır.

\section{Teşekkür}

Bu çalıșmada kullanılan veriler, SDÜ Bilimsel Araştırma Projeleri Koordinasyon Birimi tarafindan desteklenen olan BAP-4672-YL1-16 no'lu "Bat1 Akdeniz Yöresi Doğal Sedir (Cedrus libani A. Rich) Meşcereleri İçin Ağaç Hacim Denklemlerinin Geliştirilmesi” isimli proje çalışmasında elde edilmiştir.

\section{Kaynaklar}

Akindele, S.O., LeMay, V.M., 2006. Development of tree volume equations for common timber species in tropical rain forest area of Nigeria. Forest Ecology and Management, 226: 41-48.

Alegria, C., Tome, M., 2011. A set of models of individual tree merchantable volume prediction for Pinus pinaster Aiton in central inland of Portugal. European Journal of Forest Research, 130:871-879.

Bailey, R.L., 1995. Upper stem volumes from stem analys is data: an overlapping bolts method. Can J. For. Res., 26(1): 170-173.

Baskerville, G.L., 1972. Use of logarithmic regression in the estimation of plan biomass. Canadian Journal of Forest Research, 2:49-53.

Bi, H., Hamilton, F., 1998. Stem volume equations for native tree species in southern New South Wales and Victoria. Australian Forestry, 61(4): 275-286.

Boydak, M., 2003. Regeneration of Lebanon cedar (Cedrus libani A. Rich.) on karstic lands in Turkey. Forest Ecology and Management, 178: 231-243.

Bozkuș, H.F., Carus, S., 1997. Toros göknarı(Abies cilicica Carr.) sedir (Cedrus libani Link.)'in çift girişli gövde hacmi tabloları ve mevcut tablolarla karsılastırılması. Journal of the Faculty of Forestry İstanbul University (JFFIU), 47(1): 51-70.

Brooks, J.R., Jiang, L., Özçelik, R., 2008. Compatible stem volume and taper equations for Brutian Pine, Cedar of Lebanon, and Cilicica Fir in Turkey. Forest Ecology and Management, 256:147-151.

Brooks, J.R., Wiant, H.V., 2008. Ecoregion based local volume equations for Appalachian hardwoods. Northern Journal of Applied Forestry, 25(2): 87-92.

Burk, T. E., 1989. Individual Tree volume equations for The Northeastern United States: Evaluation and new form quotient board foot equations. Northern Journal of Applied Forestry, 6(1):27-31.

Burkhart, H.E., Tome, M., 2012. Modeling forest trees and stands. Springer, Dordrecht.

Castedo-Dorado, F., Gomez-Garcia, E., Dieguez-Aranda, U., Barrio-Anta, M., Crecente-Campo, F., 2012. Aboveground stand-level biomass estimation: a comparis on of two methods for major forest species in northwest Spain. Annals of Forest Science, 69: 735-746.

Clutter, J.L., Fortson, J.C., Pienaar, L.V., Bailey, R.L., 1983. Timber management: A quantitative approach. Krieger Publishing Company, Malabar, Florida.

Crecente-Campo, F., Alboreca, A.R., Dieguez-Aranda, U., 2009. A Merchantable volume system for Pinus sylvestris $\mathrm{L}$. in the major mountain ranges of Spain. Annals of Forest Science, 66-808.

de-Miguel, S., L. Mehtatalo, Z. Shater, B. Kraid, T Pukkala., 2012. Evaluating marginal and conditional predictions of taper models in the absence of calibration data. Can. J. For. Res., 42: 1383-1394.

Dieguez-Aranda, U., Castedo-Dorado, F., AlvarezGonzalez, J.G., Rojo, A., 2006. Compatible taper function for Scots Pine plantations in Nortwestern Spain. Canadian Journal of Forest, 36(5): 1190-1205. 
Evcimen, B.S., 1963. Türkiye Sedir ormanlarının ekonomik önemi, hasılat ve amenajman esasları. Orman Genel Müdürlüğ̈̈ Yayını, İstanbul.

Fang, Z., Borders, B.E., Bailey, R.L., 2000. Compatible volume taper models for loblolly and slash pine based on system with segmented-stem form factors. Forest Science, 46: 1-12.

Fowler, G.W., 1997. Individual tree volume equations for Red Pine in Michigan. Northern Journal of Applied Forestry, 14:53-58.

Gomez-Garcia, E., Crecente-Campo, F., Barrio-Anta, M., Dieguez-Aranda, U., 2015. A disaggregated dynamic model for predicting volume, biomass and carbon stocks in even-aged pedunculate oak stands in Galicia (NW Spain). European Journal of Forest research, 134: 569583.

Hjelm, B., Johansson, T., 2012. Volume equations for poplars growing on farmland in Sweden. Scandinavian Journal of Forest Research, 27:561-566.

Honer, T., 1967. Standard volume tables and merchantable conversion factors for the commercial tree species of central and eastern Canada. For Manage Res and Serv Inst, Inf Rep FMR-X-5, Ottawa.

Husch, B., Beers, T.W., Kershaw, T.A., 2003. Forest mensuration, Wiley 4, NewYork.

Jiang, L., Brooks, J.R., Wang, J., 2005. Compatible taper and volume equations for yellow-poplar in West Virginia. Forest Ecology and Management, 213: 399409.

Kelly, T.F., Beltz, R.C., 1987. A Comparis on of tree volume estimation models for forest inventory, USDA Forest Service, Southern Forest Experiment Station, Research Paper SO-233.

Misir, N., Misir, M., 2004. Developing double-entry tree volume table for Ash in Turkey. Kafkas Üniversitesi, Artvin Orman Fakültesi Dergisi, 3(4):135-144.

Özçelik, R., 2008. Comparis on of formulae for estimating tree bole volumes of Pinus sylvestris. Scandinavian Journal of Forest Research, 23: 412-418.

Özkurt, A., 2000. Okaliptüs (Eucalyptus grandis W. Hill ex. Maiden) için hacim tablosu. Doğu Akdeniz Ormanc1lk Araştırma Enstitüsü Dergisi, 6: 87-105.

Perez, D., 2008. Growth and volume equations developed from stem analys is for Tectora grandis in Costa Rica. Journal of Tropical Forest Science, 20: 66-75.

Pillsbury, N.H., McDonald, P.M., Simon, V., 1995. Reliability of Tanoak volume equations when applied to different areas. Western Journal of Applied Forestry, 10(2): $72-78$.
Poudel, K.P., Cao, Q.V., 2013. Evaluation of methods to predict Weibull parameters for characterizing diameter distributions. For. Sci., 59(2): 243-252.

Rachid Casnati, C., Mason, E.G., Woollons, R., Resquin, F., 2014. Volume and taper equations for P. taeda (L.) and E. grandis (Hill ex. Maiden). Agrociencia Uruguay, 18(2): 47-60.

Ritchie, M.W., Hann, D.W., 1984. Nonlinear equations for predicting diameter and squared diameter inside bark at breast height for Douglas-fir. Oregon State University, Forest Research Lab., 47: 1-17.

Rodriguez, F., Lizarralde, I., Fernandez-Landa, A., Condes, S., 2014. Non-destructive measurement techniques for taper equation development: a study case in the Spanish Northern Iberian Range. European Journal of Forest Research, 133: 213-223.

Sakıc1, O.E., Yavuz, H., 2005. Kastamonu-Bostan yöresi Uludağ Göknarı meşcerelerinde gövde profili denklemleriyle biyokütle miktarının belirlenmesi. Gazi Üniversitesi Kastamonu Orman Fakültesi Dergisi, 5(1): 7-22.

Saraçoğlu, N., 1988. Kızılağaç (Alnus glutinosa Gaertn subsp. Barbata (C.A. Mey.) Yalt.) gövde hacim ve biyokütle tablolarının düzenlenmesi. Doktora Tezi, Karadeniz Teknik Üniversitesi, Fen Bilimleri Enstitüsü, Trabzon.

Schumacher, F.X., Hall, F.D.S., 1933. Logarithmic expression of timber-tree volume. J. Agric. Res., 47: 719-734.

Scott, C.T., 1981. Northeastern forest survey revised cubicfoot volume equations. USDA Forest Service, Northeastern Forest Experiment Station, Res earch Note NE-304.

Takata, K., 1958. Construction of universal diameter-heightcurves. Journal of Japanese Forest Society, 40:1.

Teshome, T., 2005. Analysis of individual tree volume equations for Cupressus Lusitanica in Munessa Forest, Ethiopia. Southern African Forestry Journal, 203: 27-32.

Van Larr, A., Akça, A., 1997. Forest mensuration. Cuvillier Verlag, Göttingen.

Yavuz, H., 1999. Taşköprü yöresinde Karaçam için hacim fonksiyonları ve hacim tabloları. Turkish Journal of Agriculture and Forestry, 23: 1181-1188. 